Каргіна Наталія

кандидат психологічних наук, старший викладач кафедри практичної психології Одеського національного морського університету

ORCID iD: 0000-0003-0091-8906

DOI https://doi.org/10.35619/prap_rv.vi13.119

\title{
ОСОБЛИВОСТІ НАДАННЯ ПСИХОЛОГІЧНОЇ ДОПОМОГИ ОСОБАМ 3 НИЗЬКИМ РІВНЕМ ПСИХОЛОГІЧНОГО БЛАГОПОЛУЧЧЯ: МОЖЛИВОСТІ ТА ОБМЕЖЕННЯ
}

Анотація. $У$ статті надаються рекомендації практичним психологам, щуо спрямовані насамперед на підвищення загального рівня психологічного благополуччя особистості. У роботі з особами із низьким рівнем психологічного благополуччя, практичний психолог на перших етапах своєї роботи може використовувати бесіду, йому також можуть знадобитися різноманітні арт-терапевтичні методики; відзначаються можливості та обмеження психологічного супроводу осіб із низьким рівнем психологічного благополуччя. Робота щодо підвищення психологічного благополуччя носить досить складний та комплексний характер, й може містити в собі гармонізацію власного психічного стану, різноманітні техніки релаксації, формування та закріплення соціальних навичок, здатність людини інтегрувати особистий пережитий травматичний досвід, включати його в автонаратив, досягнення балансу між внутрішньою автономією i навичками взаємодії з оточенням; підвищувати власну самоефективність завдяки активізації відповідальності за своє майбутнє, суто клінічні інтервенції при необхідності тощу.

Ключові слова: благополуччя, психологічне благополуччя, особистість, надання психологічної допомоги.

Постановка проблеми. Одночасно 3 тим, як все більше розкривається сутність психологічного благополуччя, його критерії та взаємозв'язку з іншими характеристиками особистості, в рамках зарубіжної психотерапевтичної традиції розвивається модель терапії психологічного благополуччя - Well-being therapy (Fava, Ruini, 2003). В даній роботі показано, що загальний рівень психологічного благополуччя підвищується, якщо поетапно коригувати кожен з його компонентів - актуалізувати почуття автономії і самостійності, визначати життєві цілі та особистісні смисли, допомагати в усвідомленні меж і можливостей власної компетентності в управлінні навколишньою дійсністю, збалансувати рівень самоприйняття і самопізнання, визначити критерії власного особистісного росту і створення образу ідеального «Я», а також вибудувати конструктивні взаємозв'язки та соціальні відносини з іншими людьми (Fava, Ruini, 2003). 3 огляду на втрати, які походять від негативних емоцій, велике значення набуває профілактика індивідуальних та суспільних проблем, які випливають з негативних емоцій. Психолог спрямовує клієнта на запобігання або пом'якшення проблемних негативних емоцій, що саме по собі не означає культивування позитивних емоцій. Позитивні емоції - це більше, ніж відсутність негативних. Здатність відчувати позитивні емоції залишається значною мірою невикористаним ресурсом людського потенціалу та іiі психологічного благополуччя. Важливою особливістю позитивних емоцій $є$ те, що їх дія не закінчується після запобігання страждань. Наслідки позитивних емоцій резонують й надалі. Позитивні емоції не тільки свідчать про те, що людина відчуває себе добре сьогодні, а й збільшують ймовірність того, що вона буде відчувати себе добре й в майбутньому, тобто позитивні емоції сприяють підвищенню ії психологічного благополуччя, що обов'язково треба враховувати психологу під час надання психологічної допомоги (Fava, Ruini, 2003). 
Аналіз останніх досліджень 3 проблеми. Сьогодні українськими психологами досліджуються такі напрямки дослідження даного феномену, як: психологічне благополуччя учасників антитерористичної операції (Ващенко); особливості взаємозв'язку релігійної активності та благополуччя (Савелюк); благополуччя в контексті соціальних потреб та соціального порівняння (Данильченко) тощо.

Мета статті полягає в розгляді особливостей надання психологічної допомоги особам із низьким рівнем психологічного благополуччя.

Виклад основного матеріалу. Рекомендації практичним психологам спрямовані насамперед на підвищення загального рівня психологічного благополуччя особистості. Робота із особливостями психологічного благополуччя особистості, носить досить складний та комплексний характер й може містити в собі гармонізацію власного психічного стану, різноманітні техніки релаксації, формування та закріплення соціальних навичок, суто клінічні інтервенції при необхідності тощо. Значну роль у роботі із особами із низьким рівнем психологічного благополуччя відіграє психотерапія, що виконує «протекторну» та «модуляційну» роль, пом'якшуючи реактивність структурного атрактора негативних чинників та спрямовуючи адаптаційно-компенсаторні механізми в сприятливий бік, що позитивно позначається на психологічному благополуччі людини в цілому (Неруш, 2010).

У психотерапевтичній роботі з людьми, які гостро переживають психологічне неблагополуччя особливо важливо виділити ті внутрішні ресурси особистості, що містяться в позитивно оцінюваних ситуаціях, подіях, що сталися або відбуваються в їх повсякденному житті, а також створити необхідні умови для переоцінки тих подій, які стають джерелом негативних переживань, незадоволення. Все це вимагає введення специфічних елементів в роботу 3 конкретним клієнтом, спираючись на теоретичні знання в проектуванні психотерапевтичного процесу. Досить важливим буде акцентувати увагу на тому, що «все не марно», значимо й, навіть, необхідно, щоб поліпшити власне психологічне благополуччя. Необхідно страждання, необхідно задоволення, необхідна допомога іншому навіть можливо через власні витрати, і невпевненість у чомусь, але людині треба впоратися з усіма життєвими негараздами або смисловим вакуумом, що вимагає певної роботи ії душі (Неруш, 2010). Працюючи із особою із низьким рівнем психологічного благополуччя, психолог у своїй роботі, звертаючись до основ гештальт-психології, звертає увагу на те, що відчуття психологічного благополуччя приходить, коли людина має здатність жити «тут і зараз», тобто проживати всі емоції та почуття, які виникають в даний момент - не відриваючись від них і не «відлітаючи» у власне минуле або майбутнє. Саме в ці моменти людина знаходить почуття життєвої наповненості, відчуття, що вона не дарма проживає життя, радості від усвідомлення себе й навколишнього світу (Перлз, 2007). Важливим $\epsilon$ й те, що усвідомлення власних кордонів дозволяє розуміти, за що людина відповідає, що належить саме їй і за які наслідки вона несе відповідальність. Тоді стає можливим пошук рівноваги між власними бажаннями, і відповідно, способом дії з умовами зовнішнього світу і потребами іншої людини, що, безперечно, має вплив на ії психологічне благополуччя та здоров'я. Важливим завданням психолога $є$ допомога особі окреслити (осягнути) «коло довіри», виходячи з їі особистого життєвого досвіду. Його розширення чи звуження як мета психологічної роботи та допомоги може виступати виключно за запитом самого клієнта у випадку, коли наявний рівень довіри знижує й рівень загального психологічного благополуччя людини (Данильченко, 2014). Отже, допомога полягає в досягненні більшої психологічної незалежності через переосмислення власних досягнень, зростання самоповаги та самоцінності, усвідомлення та прийняття власної відповідальності за здійснений життєвий вибір та за своє психологічне благополуччя зокрема, здійснення відповідної психологічної підтримки.

На наш погляд, ключовою проблемою, яка обмежує розвиток особистості з низьким рівнем психологічного благополуччя, $\epsilon$ жорстко фіксованою, настороженою та характеризується негативним ставленням до інших людей, світу та власної особистості. В свою чергу, подібні відносини ставлять своєрідні психологічні бар'єри у можливості встановлення конструктивних соціальних контактів, блокуючи тим самим можливість зміни 
особистості за рахунок встановлення щирого екзистенціального діалогу з іншими людьми та в першу чергу із собою, характеризуючись занепадом власних цінностей, світоглядної та екзистенційної складової. Загальною метою психологічної допомоги для такої особи може стати, з одного боку, концентрація на справжніх життєвих потребах, світоглядній складовій та цінностях особистості, які до цього моменту залишалися актуальними для самої людини, вважаючи за краще змінювати суб'єктивне ставлення заради підтримки власного психологічного благополуччя 3 обов'язковою перспективою на майбутнє (Данильченко, 2014). Зазначимо, що психологу варто навчити особистість із низьким рівнем психологічного благополуччя успішно переосмислювати власні пережиті травматичні переживання, що, 3 часом можуть призводити до розриву між іiі минулим, теперішнім та майбутнім, його викривленості, адже минуле викликає лише негативні спогади, сьогодення характеризується невлаштованістю, а майбутнє досить туманне. Спеціаліст в жодному разі не заперечує дані переживання особистості, а включає їх усі у власну автобіографію людини, вчить ії правильно опрацьовувати їх; дає можливість для адекватного прояву та прийняття почуття власного страху, гніву, розпачу, образи, агресії, радості, любові, симпатії тощо; в першу чергу, навчаючи особистість бути відповідальною у ставленні до свого життя; усвідомлювати цінність та значимість особистого психологічного благополуччя; розвивати рефлексію своєї поведінки; здатність приймати допомогу оточення та надавати іiі іншим. Важливим аспектом роботи психолога та клієнта з відновлення психологічного благополуччя особистості є вивчення передісторії травм (Франкл, 2000). В свою чергу, пережита травма, яка нібито має хворобливий вплив на психологічне благополуччя особистості, насправді $\epsilon$ поштовхом до глибшого розуміння своєї природи та даності, проявлення того, що раніше не приймалося людиною та не усвідомлювалося нею в повній мірі.

Таким чином, працюючи із особами із низьким рівнем психологічного благополуччя психолог у першу чергу повинен зробити так, щоб пережиті травмуючи події та переживання призводили до того, щоб людина прагнула зменшити невідповідність між їх життєвим досвідом та глобальною системою власних поглядів. Коли людина в змозі пристосувати особисті глобальні вірування та свій життєвий досвід так, щоб цю невідповідність було зменшено, негативні наслідки травмуючих подій та переживань поступово знижуються,

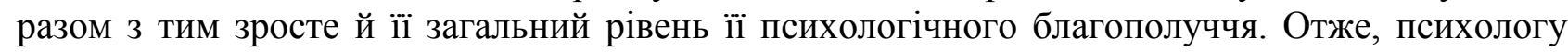
слід допомогти людині побороти бездонну порожнечу всередині себе, яка забирає ресурси їі психологічного благополуччя, розщеплює особистість та прирікає іiі на поневіряння по пустелі невпевненостей та морального самознищення. Залежно від специфіки ставлення до інших людей та готовності вступати 3 ними у взаємодії, відрізняється й форма надання психологічної допомоги клієнту. Так, для особистості із низьким рівнем психологічного благополуччя повинен відбутися поступовий перехід від індивідуальної роботи до групової взаємодії, враховуючи всі їі особливості характеру (Франкл, 2000).

Групова та індивідуальна робота повинна бути організована таким чином, щоб кожен учасник мав змогу усвідомити власні переживання, ті, що пов'язані із суб'єктивним відчуттям свого психологічного благополуччя, зрозуміти їх індивідуальну значущість та виробити можливі стратегії зміни та корекції в залежності від змін життєвих обставин. Варто зробити акцент на аналізі виникаючих асоціацій та спогадів, котрі стимулюють різноманітні арт-терапевтичні методики. Пропонуємо звернути увагу на не тільки традиційні малюнкові тести, зокрема, такі як, «Людина під дощем», але й методику «Дощ у казковій країні», яка актуалізує ресурсні переживання психологічного благополуччя, стимулює формування почуття перспективи та власної захищеності (Неруш, 2010). Отже, використання у тренінговій роботі «дощової» серії малюнків дозволяє зрозуміти характер поведінки людини у несприятливих умовах та знайти необхідні ресурси протистояння даним впливам середовища. Також вважаємо досить цікавою та сучасною технікою у арт-терапії методику «Мандала», яка може бути використана у роботі із психологічним благополуччям практичним психологом. Юнг (1994) стверджував, що мандала відповідає мікроскопічній природі душі людини. Цей малюнок у колі використовують для роботи з клієнтами будьякого віку та діагностики й корекції безлічі існуючих проблем. Переваги методу «Мандала» 
у вивченні психологічного благополуччя особистості полягають у швидкості отримання даних про актуальний психологічний стан клієнта. Також малювання «мандали» як проекції внутрішнього світу не викликає опору клієнта та відповідно не актуалізує захисні механізми. Окрему увагу варто звернути психологу з використанням таких арт-корекційних технік для роботи 3 психологічним благополуччям особистості, як: «Портрет страху», «Чарівні дзеркала», «Безпечний світ», «Маска страху», «Перетворення страхів» (Неруш, 2010).

Висновки і перспективи подальших розвідок. Таким чином, беручи факт того, що психологічне благополуччя тепер вже не розуміється лише як відсутність неблагополуччя, а як самостійний феномен, який має свої структурні компоненти, з'являється можливість розширити можливості психотерапевтичної роботи із клієнтом, тим самим підвищуючи загальний рівень психологічного благополуччя особистості. Отже, зазначимо, що робота психолога із особами з низьким рівнем психологічного благополуччя має з однієї сторони сконцентруватися на особистісному життєвому досвіді та переживаннях, на власному психологічному благополуччі, а 3 іншого - навчитись правильно встановлювати контакт 3 іншими, вступаючи у взаємовплив, відкрито та правдиво виражаючи особисті думки та почуття 3 приводу обговорюваних тем, не приховуючи від себе неприємні сторони власного я. Звісно, важливою є робота з психологічним благополуччям як ефективною терапевтичною стратегією, яка передбачає, що відсутність стану благополуччя сприяє уразливості особистості, і що шлях до його відновлення полягає не тільки в полегшенні негативних симптомів, але і в підвищенні психологічного благополуччя в цілому, яке покращує індивідуальну стійкість та формує буфер проти життєвих стресів.

Перспективи дослідження полягають у пошуку можливостей ефективного соціальнопсихологічного супроводу осіб із низьким рівнем психологічного благополуччя. Планується виокремити ефективні стратегії сприяння конструктивним особистісним трансформаціям 3 метою укріплення психологічного благополуччя особистості.

\section{СПИСОК ПОСИЛАНЬ}

Данильченко, Т. (2014). Об'єктивні фактори суб'єктивного благополуччя. Актуальні проблеми психології. Психологія особистості. Психологічна допомога особистості, 13, 165-176.

Неруш, Т. (2010). Психодиагностика. Саратов: Саратовский государственный социальноэкономический университет.

Перлз, Ф. (2007). Гештальт-подход. Свидетель терапии. Москва: Институт психотерапии.

Франкл, В. (2000). Воля к смыслу = The will to meaning. Москва: Апрель Пресс; ЭКСМОПресc.

Юнг, К. (1994). Собрание сочинений. Конфликты детской души. Москва: Канон.

Fava, A., \& Ruini, C. (2003). Development and characteristics of a well-being enhancing psychotherapeutic strategy: well-being therapy. Journal of Behavior Therapy and Experimental Psychiatry, 34, 207-218.

\section{REFERENCES}

Danylchenko, T. (2014). Obiektyvni faktory subiektyvnoho blahopoluchchia [Objective factors of subjective well-being]. Aktualni problemy psykholohii. Psykholohiia osobystosti. Psykholohichna dopomoha osobystosti, 13, 165-176. [in Ukrainian].

Nerush, T. (2010). Psihodiagnostika [Psychodiagnostics]. Saratov: Saratovskij gosudarstvennyj social'no-ekonomicheskij universitet. [in Russian].

Perlz, F. (2007). Geshtal't-podhod. Svidetel' terapii [Gestalt approach. The witness of therapy]. Moskva: Institut psihoterapii. [in Russian].

Frankl, V. (2000). Volya k smyslu = The will to meaning [Will to meaning]. Moskva: Aprel' Press; EKSMO-Press. [in Russian].

Yung, K. (1994). Sobranie sochinenij. Konflikty detskoj dushi [Collected works. Conflicts of the child's soul]. Moskva: Kanon. [in Russian]. 
Fava, A., \& Ruini, C. (2003). Development and characteristics of a well-being enhancing psychotherapeutic strategy: well-being therapy. Journal of Behavior Therapy and Experimental Psychiatry, 34, 207-218. [in English].

\title{
FEATURES PSYCHOLOGICAL ASSISTANCE PEOPLE WITH LOW PSYCHOLOGICAL WELL-BEING: OPPORTUNITIES AND CONSTRAINTS
}

Natalya Karhina

Candidate of Psychology, Senior Lecturer in the Department of Practical Psychology

Odessa National Maritime University

ORCID iD: 0000-0003-0091-8906

DOI https://doi.org/10.35619/prap_rv.vi13.119

\begin{abstract}
The article provides recommendations to practical psychologists, who are primarily aimed at improving the overall level of psychological well-being of the individual. In working with people with low levels of psychological well-being, practical psychologist in the early stages of their work can use conversation, it can also take a variety of art therapy techniques; characterized possibilities and limitations of psychological support for people with low levels of psychological well-being.

Thus, work to enhance psychological well-being is quite complex and complex, and may include the harmonization of one's mental state, various techniques of relaxation, formation and consolidation of social skills, the ability of a person to integrate personal traumatic experience, to include it in self-narrative, to achieve balance between autonomy and interaction skills; to increase one's self-efficacy through increased responsibility for one's future, purely clinical interventions, if necessary, etc.
\end{abstract}

Key words: well-being, psychological well-being, personality, providing psychological help.

Стаття надійшла до редакиії 14.10.2019 р. 